\title{
Analysis of Creativity and Innovation Chemistry Education Students Through Chemo-Entrepreneurship-Oriented Product Assessment Model
}

\author{
Dila Fairusi ${ }^{1}$, Erina Hertanti ${ }^{2}$, Nanda Saridewi ${ }^{1}$ \\ \{dila.fairusi@uinjkt.ac.id ${ }^{1}$, erina.hertanti@uinjkt.ac.id ${ }^{2}$, nanda.saridewi@uinjkt.ac.id ${ }^{3}$ \} \\ 1,2,3 UIN Syarif Hidayatullah Jakarta, Indonesia
}

\begin{abstract}
This study aims to analyze the creativity and innovation of Chemistry Education students through chemo-entrepreneurship oriented product assessment models. The subjects in this study were all Chemistry Education students who were taking Biotechnology and Food Chemistry courses. This research used descriptive method with one-shot case study experimental design. Data collection in research used direct observation techniques. These data were analyzed using quantitative descriptive analysis. The research results obtained were the creativity and innovation of students who are given treatment got grades with very good categories. The chemo-entrepreneurship (CEP) approach was successfully applied in this study by providing project assignments in groups. This research is expected to provide information on the concept of integrating entrepreneurial spirit both in learning and assessment as an effort to increase the creativity and innovation of the nation's generation.
\end{abstract}

Keywords: creativity, innovation, chemo-entrepreneurship, product assessment

\section{Introduction}

Naturally, the potency of creativity and innovation is owned by everyone. But the growth and development of each person will be different, depending on each opportunity to develop it. Creativity can be developed through increasing the number and variety of inputs to the brain, especially about new things. While innovation can be developed through high creativity. Creativity without innovation will not bring numerous huge changes, since innovation is a practical application of creativity to be useful and have high value.

Creativity and innovation are two distinct things, however in every case together and need one another. Creativity according to Ted Levitt is a characteristic that is always looking for new things, while innovation is a characteristic that always implements creative solutions [1]. An individual's creativity is estimated by the ability to create, manifest, discover new forms, produce something from imaginative skills, and manifest into something new [2]. Another opinion expresses that creativity is the capacity to think new and different, while innovation is the capacity to act new and different [3]. Creativity is the initial move towards innovation.

Creativity and innovation are the main provisions for a person to empower his potential and the resources around him effectively and efficiently. However, the problem is the education system in advanced education does not provide opportunities for students to develop their creativity and innovation, subsequently, universities have not been able to produce 
graduates who have a deal esteem. This can be seen from the unique phenomenon of unemployment patterns in developing countries, including Indonesia, evidently the joblessness rate is more common among those with advanced education.

The realities show that college graduates are one of the contributors to the national unemployment rate with enormous numbers. Based on data from the Badan Pusat Statistik (BPS) in February 2017, in Indonesia there were 4.98 percent $(349,098$ people) of the total unemployed who were college graduated class [4]. The issue of educated unemployment gives a warning that universities have not been able to produce graduates to be independent, so that college graduates think that its difficult to contend and have a strong dependency on government and private offices.

In Indonesia, one of the elements causing the low competitiveness is the low creativity and innovation. In fact, creativity and innovation are the 21 st century skills that must be possessed. The correct solution for conquer these issues is to strive to increase creativity and innovation through integrating the spirit and soul of entrepreneurship in learning to become successful entrepreneurs [5]. In this case, creativity and innovation are enhanced through the cultivation of an entrepreneurial culture. In college, courses that can encourage this are Biotechnology and Food Chemistry.

Biotechnology is an applied science that studies the use of living things at the animal, plant, cell and gene level to produce useful goods or services [6]. Biotechnology can be classified as conventional and modern biotechnology. Distinction between the two, which is on the working principle used. In conventional biotechnology, the manipulation of the characteristics of organisms is carried out under environmental conditions and growing media. In modern biotechnology, designing is not only done on environmental conditions and growing media, but also on the arrangement of genes in chromosomes.

Meanwhile, food chemistry is the study of food chemical processes and their interactions with biological and non-biological components of food. Biological components include food products, such as vegetables, fish, meat, milk, etc., while non-biological components are food additives, such as sweeteners, colorings, preservatives, and others. This science also studies changes in food, in its processing and how to prevent these change.

In this research, students' creativity and innovation were trained and enhanced by giving project assignments in the form of food conservation based on conventional biotechnology concepts and ideas in producing new foods. Creativity and innovation of food conservation was refer to the process of adding nutritional value, improving taste, as well as the appearance of a food ingredient so that it has a higher selling value. Creativity and innovation were assessed based on the manufacturing process and the quality of the products produced. The implication of this was the need to make congruence between assessment techniques and output targets of food project assignments. Proper assessment would provide valuable feedback for the learning process.

Evaluation recommendations to these criteria were chemo-entrepreneurship (CEP) oriented product assessment models. Product assessment is an assessment of the manufacturing process and product quality [7]. While chemo-entrepreneurship is a contextual chemical learning approach, where the learning approach is directly related to real objects or phenomena around life. The CEP approach allows students to study the process of processing a material into a product that is useful, has economic value, improves soft skills, and motivates the spirit of entrepreneurship [8, 9]. In addition, the CEP approach can be applied to improve achievement in learning and life skills of students [10]. The essence of the CEP approach is creativity and innovation. This means the CEP-oriented product valuation model is very congruent to be 
applied to food project assignments, since it enables students to develop and enhance their creativity and innovation.

Based on these considerations, this study intends to investigate the results of the analysis of creativity and innovation of Chemistry Education students based on chemoentrepreneurship oriented product assessment models. The method used was descriptive quantitative method.

\section{Method}

This research was conducted at the Chemistry Education Program, Tarbiya and Teacher Training Faculty UIN Syarif Hidayatullah Jakarta. The sampling technique in this study used a purposive sampling technique with specific considerations. The sample were Chemistry Education students taking Biotechnology and Food Chemistry courses.

This research used a descriptive quantitative method. This method could describe the research carried out, in particular investigating student creativity and innovation through a chemo-entrepreneurship oriented product assessment model. Meanwhile, the design used in the study was a one-shot case study experiment [11]. This design was implemented by giving project assignments as a treatment then observing the results obtained.

The instrument used to collect data in the study was an observation sheet in a rating scale form. In this study, the observation sheet used was a systematic observation sheet. Systematic observations are observations that are carried out systematically, which means that all categories to be measured meet the criteria expected by the researcher [12]. The observation sheet contains 25 statements. The statements consisted of 18 statements for indicators of creativity, which its indicators were fluency, originality, flexibility, and elaboration [13]. Beside it, 7 statements for indicators of innovation which the indicators of innovation were conveying ideas, implementing creative solutions, and exploring new territory. The observation sheet was validated by two experts before being used for data collection. Observations in this study were carried out by two observers.

The rating scale used on the observation sheet refers to a Likert scale with a range of $1-5$. Scores 1, 2, 3, 4, and 5 in a row for very less, less, enough, good, and very good criteria. Data analysis of the observation sheet was done by calculating the value obtained indicators of creativity and innovation that are measured, through (1) and (2) [11].

Ideal score $=$ (number of indicators / aspects) $\mathrm{x}$ maximum score Value $=($ number of scores obtained $/$ ideal score $) \times 100$

The values obtained were further classified into categories, namely $20 \leq$ value $<36$ very less, $36 \leq$ value $<52$ less, $52 \leq$ value $<68$ enough, $68 \leq$ value $<84$ good, and $84 \leq$ value $<100$ very good [14].

\section{Result and Disscussion}

This research was conducted on students who take Biotechnology and Food Chemistry courses. Students were given project assignments to produce new products or innovation products. This task was done in groups (cooperatively) so that the CEP approach is truly workable for students to improve collaboration and communication [15]. There were 11 groups that have done the task. 


\subsection{Chemo-Entrepreneurship Oriented Product Assessment}

The assessment model conducted on student assignments was a chemo-entrepreneurship oriented product assessment model. This kind of assessment used an observation sheet instrument which was carried out in three stages: the preparation, product manufacturing, and product evaluation stages. The assessment system applied was an assessment of the process and results, it meant that every stage that was passed by students in the implementation of the project would have an assessment.

The first stage was the stage of preparation. The preparation stage assessment included the ability to explain ideas about the product to be made, how to make it, the tools and materials used, and the benefits of the product. Discussions between groups occur at this stage to provide advice and input for the implementation of this task well.

Second, the product manufacturing stage. Each group started an experiment to make a product. The process of making a product was tried several times to get the best results. The evaluation requirements at this stage were skills in using tools and materials, using work methods correctly, being able to modify work methods to make it easier and successful in the work process, and maintaining workplace hygiene. Product marketing was also planned at this stage.

Some groups were able to make several distinct products from the same basic ingredients. As a result, the products produced in one group become assorted.

Last, the assessment product stage. Each group presented the results of their project work. The explanation covered the process of making products, products that have been made, and the results of product marketing by displaying images or videos. Each group's report was completed by a selling financial report.

From this project assignment, students produced 19 new products and innovations, which consist of 5 simple Biotechnology products and 14 Food Chemistry products. Simple biotechnology products were purple sweet potato donuts, moringa leaf donuts, nata de tomato, banana skin yogurt, and dragon fruit skin yogurt. Meanwhile, the Food Chemical products were mushroom meatballs (vegetarian meatballs), green bean chicken nugget, chocolate tofu pudding, purple sweet potato kelepon, purple sweet potato with fermented soybean fried dumplings, purple sweet potato pudding, spinach pastel, kembang goyang spinach, spinach sushi, moringa cilok, moringa pie, chips pumpkin with original and chocolate flavored, pumpkin brownies, and pumpkin layers cake.

\subsection{Students Creativity and Innovation}

Some of the characteristics of creative people mentioned by Guilford, including fluency, flexibility, originality, and elaboration [13]. These characteristics were used as indicators in observing student creativity. Observations were carried out at each stage of the project, so that student creativity could be observed in each stage. The results obtained are in Figure 1. It shows that the student creativity observation results were in very good category in each category. The flexibility indicator got the highest score.

Observation aspects on indicators of flexibility (and their value) consisted of a) capable of utilizing the devices as indicated by the techniques (100), b) using materials that were planned $(94.55), \mathrm{c})$ done procedures that has been set up to complete the project $(87.27)$, d) keep up working environment cleanliness (100), (e) have confidence in selling products and serving buyers (96.36), and (f) have a solid team and work together (92.73). From the six aspects of observation, observation aspects capable of utilizing the devices as indicated by the techniques 
and keep up working environment cleanliness got the best value. In the manufacture of food products, expertise in the use of tools must be had. Besides it, cleanliness of the working environment should be kept up so that the resulting food products become hygienic.

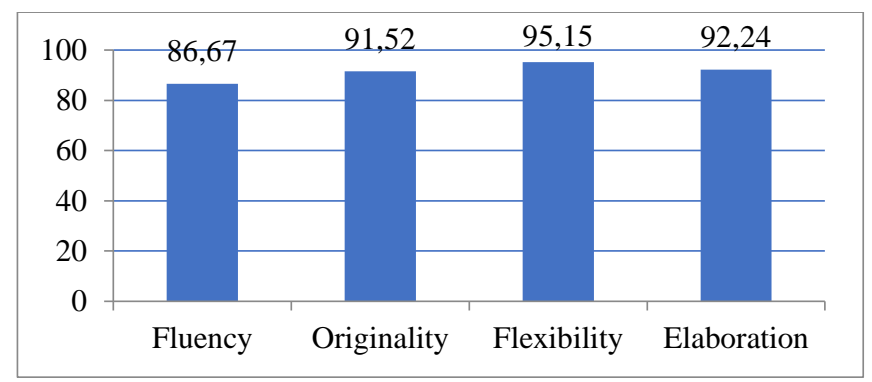

Fig.1. Student Creativity Observation Results

Another very important observation aspect is have confidence in selling products and serving buyers. Mental capital which has the best impact in doing business, that is an optimistic attitude, willing to work hard, and dare to take risks in building a business [16].

Indicators of fluency are reflected in the delivery of many ideas and solutions quickly and logically. Observations made in this indicator were a) able to convey many ideas with confidence (78.18), b) have many strategies in product sales (85.45), and c) have the will to generate large profits $(96,36)$. Based on observations, at an early stage students are only able to give one or two new product ideas and how they work. After continuing to practice making products and discussing, students are able to provide many ideas or strategies to do their project work, so that the task can be done well [15].

Original skills were reflected in the following aspects of observation, a) capable to convey new ideas (83.64), b) capable of completing projects (96.36), and (c) products produced according to the proposed ideas $(94,55)$. Based on observations, students were able to convey new ideas and transform them into products.

Elaboration observation aspects included: a) capable to explain the benefits of the product to be made (100), b) finding ways of making the complete product $(94.55)$, c) finding the devices and ingredients needed $(96,36)$, d) preparing the devices and ingredients needed (94.55), e) capable to report project results in detail (94.55), and (f) the financial report of product selling were made in detail (85.45). The first four points were observed at the preparation stage, while the last two points were observed at the product assessment stage. Based on observations, all aspects got a score with a very good category. These shown that students have succeeded in detailing their ideas at the preparation stage into the next work steps that must be done in project assignments [17].

The second variable analyzed in this study is Chemistry Education student innovation. The innovation indicators used in this research were conveying ideas, implementing creative solutions, and exploring new territory. Student innovations observation results in Table 1 show that the average observation obtained a very good category.

The highest observation aspect value was seen in the aspect of looking for ingredients that are in accordance with local wisdom or utilize ingredients that have not been used before, which is 100, very good category. Almost all groups used basic ingredients in accordance with local wisdom, such as purple potato, moringa leaves, pumpkin, spinach, green beans, tofu, banana peels, tomatoes, and dragon fruit. Students were able to make these basic ingredients 
into foods that have a good taste. As a result, the selling value of these basic ingredients increased after the food were made.

Tabel 1. Students Innovation Observation Results

\begin{tabular}{|c|c|c|c|c|c|}
\hline No. & Indicator & & Observations Aspect & Value & Category \\
\hline \multirow[t]{3}{*}{1} & Conveying ideas & a) & $\begin{array}{lll}\begin{array}{l}\text { Performing updates of } \\
\text { products. }\end{array} & & \text { existing } \\
\end{array}$ & 90.91 & Very good \\
\hline & & b) & $\begin{array}{l}\text { The product produced is a new product } \\
\text { or modify an existing one. }\end{array}$ & 90.91 & Very good \\
\hline & Average indicator & & & 90.91 & Very good \\
\hline \multirow[t]{3}{*}{2} & $\begin{array}{l}\text { Implementing creative } \\
\text { solutions }\end{array}$ & c) & $\begin{array}{l}\text { If no devices are needed, students were } \\
\text { able to use other alternatives (other } \\
\text { easier devices). }\end{array}$ & 87.27 & Very good \\
\hline & & d) & $\begin{array}{l}\text { Providing good service to consumers } \\
\text { so that consumers become satisfied. }\end{array}$ & 98.18 & Very good \\
\hline & Average indicator & & & 92.73 & Very good \\
\hline \multirow[t]{5}{*}{3} & Exploring new territory & e) & $\begin{array}{l}\text { Looking for ingredients that are in } \\
\text { accordance with local wisdom or } \\
\text { utilize ingredients that have not been } \\
\text { used before. }\end{array}$ & 100 & Very good \\
\hline & & f) & $\begin{array}{l}\text { Capable modify the procedures in } \\
\text { accordance with the conditions in the } \\
\text { manufacture of the product. }\end{array}$ & 89.09 & Very good \\
\hline & & g) & $\begin{array}{l}\text { Have unique breakthroughs in product } \\
\text { sales. }\end{array}$ & 74.55 & Good \\
\hline & Average indicator & & & 87.88 & Very good \\
\hline & \multicolumn{3}{|c|}{ Overall average } & 90.51 & Very good \\
\hline
\end{tabular}

Meanwhile, the lowest observation aspect value was found in the aspect of having unique breakthroughs in product sales, which is 74.55 in the good category. Students were still marketing and selling products using the old method, which is sold directly to consumers. Although, there was one group that has carried out marketing and sales through the latest social media. Product marketing through social media certainly made the product more well known in the wider community.

The observation creativity and innovation Chemistry Education students gain value with very good category. It means that Chemistry Education students had very good creativity and innovation. In this project, the students have provided new ideas on the preparation and the implementation process has innovated to implement ideas to the procedures, practices, and better products [18].

The products produced were marketed to the community to growth entrepreneurial interest in students. The results of product marketing got positive responses from buyers. The success of the product marketing process is due to the commitment and cooperation of the members [19]. In addition, creativity and innovation simultaneously influence entrepreneurship [20]. Creativity is also very important for the business continuity of entrepreneurs [21, 22]. Therefore, it becomes very important to bring out the creativity and innovation of students in learning. When students have good creativity and innovation, it will be very useful for their future. Later they are not job seekers, but job creators. 


\section{Conclusion}

Based on the research results obtained, the students creativity and innovation of the Chemistry Education Program got grades in very good category. The chemo-entrepreneurship (CEP) approach was successfully applied in this study since students carried out project assignments with enthusiasm and increased their interest in entrepreneurship.

Acknowledgments. This research was completed because of the assistance of various parties. The author would like to thank the Research and Publishing Center LP2M UIN Syarif Hidayatullah Jakarta for providing funding in the 2017 so that this research could be carried out well, students in Biotechnology and Food Chemistry courses, and all those who had assisted the implementation this research.

\section{References}

[1] T.W. Zimmerer and N.M. Scarborough, Kewirausahaan dan Manajemen Usaha Kecil. Jakarta: Salemba Empat,1996.

[2] R.R. Babu, M.M. Krishna, and A. Swathi, "Role of creativity and innovation in entrepreneurship," Innovative Journal of Bussiness and Management vol. 2, pp. 112$115,2013$.

[3] Suryana, Kewirausahaan. Jakarta: Salemba Empat, 2003.

[4] Badan Pusat Statistik (BPS), "Keadaan ketenagakerjaan Indonesia Februari 2017,” Berita Resmi Statistik, No. 47/05/Th. XX. 05 Mei 2017.

[5] S. Wijatno, Pengantar Entrepreneurship. Jakarta: Grasindo, 2009.

[6] H. Nurcahyo, Diktat Bioteknologi. Yogyakarta: Universitas Negeri Yogyakarta, 2011.

[7] Taufina, "Authentic assesment dalam pembelajaran Bahasa Indonesia di kelas rendah SD," Pedagogi, vol. IX(1), pp.113-120, 2009.

[8] Supartono, Saptorini, and D.S. Asmorowati, "Pembelajaran kimia menggunakan kolaborasi konstruktif dan inkuiri berorientasi chemo-entrepreneurship," Jurnal Inovasi Pendidikan Kimia, Vol. 3 No. 2, pp. 476-483, 2009.

[9] S.S. Sumarti, Supartono, and D. Noviyanti, "Learning tools development for chemoentrepreneurship-based hydrocarbon and petroleum in increasing the students' soft skills and interest in entrepreneurship," International Journal of Recent Advances in Multidisciplinary Research, Vol. 01, Issue 02, pp.004-009, 2014.

[10] N. Wijayanti, and W.D.R.P. Rengga, "Implementation of chemo-entrepreneurship teaching approach for improving students' life skills," Jurnal Ilmu Pendidikan, Vol. 16, No. 2, pp.100-105, 2009.

[11] Sugiyono, Metode Penelitian Pendidikan. Bandung: Alfabeta, 2008.

[12] N. Zuriah, Metodologi Penelitian Sosial dan Pendidikan. Jakarta: PT. Bumi Aksara, 2007.

[13] U. Munandar, Mengembangkan Bakat dan Kreativitas Anak Sekolah Petunjuk bagi Guru dan Orang Tua. Jakarta: PT Grasindo, 1992.

[14] P.A. Sahertian, Konsep Dasar \& Teknik Supervisi Pendidikan. Jakarta: Rineka Cipta, 2008.

[15] M. Paristiowati, R. Slamet, R. Sebastian, "Chemo-entrepreneurship: learning approach for improving student's cooperation and communication (case study at secondary school, Jakarta)," Procedia - Social and Behavioral Sciences, 174, pp.1723-1730, 2015. 
[16] R.S. Dewi, "Pengaruh faktor modal psikologis, karakteristik entrepreneur, inovasi, manajemen sumber daya manusia, dan karakteristik UKM terhadap perkembangan usaha pedagang di pasar tradisional (studi kasus pada pedagang sembako dan snack di Pasar Peterongan)," Jurnal Administrasi Bisnis, vol.2, No.1, pp.29-40, 2013.

[17] A.A. Al-Khalili, Translated by U . Farda, Mengembangkan Kreativitas Anak. Jakarta: Pustaka Al-Kautsar, 2006.

[18] N. Anderson, K. Potocnik, and J. Zhou, "Innovation and creativity in organizations: a state-of the-science review, prospective commentary, and guiding framework," Journal of Management, vol. 40, No.5, pp.1297-1333, 2014.

[19] J.M Sahut and M.P. Ortiz, "Small business, innovation, and entrepreneurship," Small Business Economics, 2013, DOI: 10.1007/s11187-013-9521-9.

[20] E. Hadiyati, "Kreativitas dan inovasi berpengaruh terhadap kewirausahaan usaha kecil," Jurnal Manajemen dan Kewirausahaan, vol.13, No.1, pp.8-16, 2011.

[21] I.R. Fillis and R. Rentschler, "The role of creativity in entrepreneurship," Journal of Enterprising Culture, 2010, DOI: 10.1142/S0218495810000501.

[22] S. Zuliarni, "Analisis kreativitas dan inovatif pengusaha industri kreatif sub sektor kerajinan di Pekanbaru,” Jurnal Aplikasi Bisnis, Vo. 4 No. 2, pp. 110-123, 2014. 